\title{
Etikken ned på jorden
}

\section{AF LARS BJERG}

Nogle tror åbenbart, vi opnår sikkerhed og klarhed og en bedre medieverden ved at udmønte de grundlæggende journalistiske værdier i etiske regelsæt. Men det er en misforståelse. Regler af den slags er enten varm luft eller snærende bånd, og så passer de næsten aldrig på situationen. Det er analyse og refleksion og diskussion af konkrete tilfælde, der flytter noget.

Hvordan får man folk til at opføre sig ordentligt? Og hvordan finder man ud af, hvad der er (mest) ordentligt at gøre i en bestemt situation?

De to simple spørgsmål er kernen i det bløppede område, vi plejer at gøre indviklet og kalde etik. Problemstillingen er ældre end ordet, og det er også kun engang i mellem, vi snakker om det under overskriften etik. Andre gange kalder vi det for eksempel børneopdragelse, ledelse, ordensregler, social kompetence, retspolitik, eller bare kvalitetskriterier og kvalitetskontrol. Men det får åbenbart en særlig pondus, når vi kalder det etik.

Etik er blevet et af de stærkeste plusord i vores sprog, og nationen taler meget om det. Vi taler om det som noget smukt, som vi har mistet og må prøve at finde igen, eller endda som noget, der er smuldret for os, så vi må bygge det op igen, helt forfra. Vi taler om, at vi må ha' os en etik, så vi sikrer os mod fejl eller almindelig forkerthed. Så vi altid ved, hvad vi skal gøre. Vi taler om, at vi må undervise nye generationer af journalister, læger, ejendomsmæglere og håndværkere noget mere i etik, så de bliver nogle bedre mennesker. Eller i det mindste, så de kan lære at opføre sig ordentligt. 
Den tankegang falder let i tråd med, at der skal være et etisk regelsæt, et codex (i.e. lovbog, nedskrevet adfærdsnorm), som man kan slå op i.

I det følgende vil jeg analysere, dels hvilken rolle etiske regler for journalistik kan spille i dagligdagens afgørelser af, hvad der skal gøres i en bestemt situation, dels hvad der ellers er på spil.

\section{Tomt sprog}

Vejledende regler for god presseskik fastslår i B5, at „Andres tillid må ikke misbruges“" (www.pressenaevnet.dk/lovgivning/index presse etik.html).

Hvilken værdi har sådan en sætning? Det turde være indlysende, at der aldrig har eksisteret en situation, hvor en journalist var i dyb tvivl og derfor slog op på B5 og fandt sit svar. Det ligger allerede i sprogets logik: Misbrug er altid forkert, for mis- betyder forkert. Det er forkert at gøre det, som er forkert, står der altså, og det kan ingen under nogen omstændigheder være uenig i. På den anden side kan de fleste journalister sagtens forestille sig situationer, om end ikke til hverdag, hvor det i al fald kan diskuteres, om ikke det er i orden at møde en kilde med en skjult dagsorden. I en væsentlig sags tjeneste. Men i det tilfælde vil man måske netop ikke sige, at man misbruger den andens tillid, højst at man bruger den. For at tjene et højere princip, som for eksempel at „klar almen interesse kræver offentlig omtale“, som det i anden sammenhæng formuleres i A1 i de Vejledende regler.

Sidste led i samme punkt B5 lider af nøjagtig samme skavank. Der står, at „Andres følelser, uvidenhed eller svigtende herredømme bør ikke misbruges.“ Igen, misbrug er selvindlysende forkert, men hvis jeg har brug for det, omdefinerer jeg min handling til ikke at være misbrug. Eller rettere, igen er det springende punkt ikke, om man må misbruge, for det må man ikke, men om en bestemt handling skal bedømmes som misbrug eller god brug.

Karl Popper har beskæftiget sig med, hvad jeg vil kalde det tomme sprog. Han pointerer, at en sætning kun kan være interessant, hvis den siger noget om virkeligheden, som potentielt kan vise sig at være forkert, når man går ud og undersøger. Eller 
som det i det mindste er muligt at være uenig i. Men som, hvis det er sandt, gør en forskel for modtageren (Popper, 1934). Et eksempel: Hvis jeg siger: 'Barndommen er en vigtig periode i ethvert menneskes liv', så er det ikke til at forestille sig, at nærmere undersøgelser skulle vise, at det er forkert. At barndommen ikke betyder noget. Men det er heller ikke til at forestille sig, at nogen skulle gide spørge stridslystent ind til belægget for påstanden. Påstanden er banal. Hvis jeg i stedet siger: 'at alt, hvad der former et menneskes personlighed, sker i de tre første leveår', har jeg strammet påstanden så meget, at den løber en meget stor risiko for at være falsk, og det kan jo i al fald i princippet undersøges empirisk. Til gengæld, hvis den viser sig sand, har den indlysende ret store implikationer. Påstanden adskiller sig fra den første derved, at den skaber skel. Mellem det, der sker i de første tre år, og det, der sker efterfølgende. Og det skel er jo spændende, især hvis det viser sig at være et sagligt funderet skel.

\section{Regler skal sætte grænser}

Oppe fra skuldrene af Popper vil jeg sige, at regler om, hvordan man skal opføre sig, skal udelukke noget. Ellers er de ligegyldige. De skal kunne bruges til at definere situationen og det, man har at gøre i situationen. Eksempel: 'Vi sætter navn på dem, der har fået mere end ét års ubetinget fængsel'. 'Alle gaver til en værdi af mere end 100 kroner skal afvises'. 'Vi viser aldrig billeder af døde mennesker fra Europa'. Den slags håndfaste regler har den indlysende fordel, at de er lette at administrere, fordi de i det store og hele udelukker tvivl og fejlskøn. Og vel også sikrer mod beslutninger, der bygger på grådighed, nepotisme, sentimentalitet og andre individuelle usaglige hensyn. De skaber ensartethed, og den enkelte behøver ikke tænke, endsige tage ansvar, han følger bare reglerne. Til gengæld sætter de pr. definition vilkårlige grænser, altså grænser, der akkurat lige så godt kunne være sat et andet sted. Og de foregiver en lighed i situationerne - om forbrydere, om gaveudveksling, om dødsfald - som ofte kan være tvivlsom.

For hvornår er to situationer ens? Det er de i én forstand aldrig. Det er denne problematik, den sunde folkelige fornuft håndterer 
talemåden 'Ingen regler uden undtagelse'. Og alligevel er det i en anden forstand netop vores evne til at abstrahere, til at se bort fra de tilfældige, uvæsentlige forskelle og komme ind til essensen af en sag eller situation, der har gjort os så succesfulde som art og kultur. Fordi det er forudsætningen for, at vi kan lære af vores erfaringer.

\section{Regler og principper på abstraktionsstigen}

For nogle - eller i nogle sammenhænge - er principper synonymt med retningslinjer eller pejlemærker. Noget, der er værd at styre efter, men som i en konkret situation kan komme i strid med et eller flere andre pejlemærker, så de bogstavelig talt skal vejes op mod hinanden: Hvad skal tillægges størst vægt i netop denne unikke situation? Retfærdighed eller barmhjertighed? Ærlighed eller venlighed? Demokrati eller effektivitet?

For andre - eller i andre sammenhænge - er principper noget absolut, fundamentalt, urokkeligt. Som netop har deres værdi ved at være gældende til hver en tid og under alle omstændigheder, fordi de hæver vore beslutninger op over de fristelser, der kunne føre os ud på et skråplan: Når det koster for meget, i penge eller bøvl eller prestige, at gøre 'det rigtige'. Eller når vi er optændte af ophidselse, så vi dybt i hjertet føler, at normale retshensyn ikke bør gælde for denne her forbryder, fordi han er så grov. Eller så optændte af sentimentalitet, så vi føler, at en anden forbryder er så sød eller har så søde børn, at vi ikke vil skrive grimt om ham her op til jul. Eller nedkølede af nepotisme eller fejhed, så vi føler, vi bør fravige normal praksis, fordi det er chefredaktørens ven, fætter eller logebror, det drejer sig om.

At holde principperne absolutte er på den ene side et værn mod vilkårlige og usaglige beslutninger og en blafrende kurs. Men det er på den anden side en stiv skabelon at lægge ned over verden, fordi det jo netop afholder beslutningstageren fra at tage en reel beslutning. Regler og principper er firkantede, men det er virkeligheden ikke.

Mens det altså er den meget konkret udformede regels styrke, at den er let at administrere efter, fordi der ikke er så meget at tage fejl af, og dens svaghed, at den er for let at administrere efter, fordi 
den ikke tager højde for virkelighedens kompleksitet, så forholder det sig ofte præcist omvendt med de abstrakt formulerede principper. Dér er højt til loftet, men måske ikke meget at rette sig efter.

Et princip kan defineres som et grundlag: En sætning, hvis sandhed forekommer indlysende, sådan at den tjener som en grundlæggende regel, en grundregel, ud af hvilken man kan udlede andre regler. Deraf følger, at det er umuligt at trække en skarp grænse mellem principper og regler, for de udgør et hierarki med mange trin på stigen, fra det mest abstrakte til det mest konkrete. Et princip/en regel på ét niveau kan altid gøres til grundlag for en mere konkret formuleret regel, som igen kan udmøntes endnu mere konkret, hvis det skal være.

Et princip som 'Pas på din troværdighed' er ret langt oppe på abstraktionsstigen. Det er ikke handlingsanvisende, og i det hele taget næppe til nogen nytte. Men det kan udmøntes, mere og mere konkret. I mellemzonen kunne det for eksempel lyde sådan her: 'Sørg for, at du aldrig bliver taget i en løgn' og 'Forbered dig altid så godt som muligt til et interview' - de er ikke rigtig operationelle, for betyder det, at man godt må lyve, bare det ikke bliver opdaget, og hvordan garderer man sig mod det? Og hvornår er forberedelsen så god som mulig? Man kunne jo altid have brugt bare lidt mere tid eller brugt sin tid bare lidt bedre.

Det overordnede princip kunne udmøntes endnu mere konkret: 'Fortæl aldrig nogen, hvad du stemmer'. 'Drik aldrig mere end én genstand, når du er på arbejde.' Og, i princippet, altid en tand mere konkret: 'Hvis du står i kø hos bageren og borgmesteren kommer ind, må du ikke tilbyde ham at komme før dig'. Men igen, spørgsmålet er, om reglen gør sit arbejde. Om den forhindrer det, den skal forhindre. Om den er nødvendig, og om den er tilstrækkelig.

\section{Stik mig en regel}

På mange af livets almindelige områder er det vældig praktisk med skarpt formulerede regler. Det er godt, at vi ikke hver for sig skal bruge tid på at finde ud af, i hvilken side af vejen vi helst vil 
køre i dag. Dér har man virkelig noget at rette ind efter. Men regler, der skal dække mere komplekse sider af livet, bliver næsten altid enten for stive eller for løse.

Hele ideen om, at livet kan løses ved hjælp af regler, er helt parallelt til troen på, at når det er svært at måle det, man stræber efter, så finder vi bare noget i nærheden, som man kan måle i stedet. Det er for eksempel svært at opstille objektive kriterier for, om en sygeplejestuderende har 'det' i sig, som kan gøre hende til en god sygeplejerske. De garvede undervisere ved godt, hvad 'det' er, og de kan ofte fornemme klart, om det er der. Men de er henvist til at teste, om den studerende kan sine teorier og procedurer, og lade det være afgørende for, om hun består eller ej. Det er hele tanken om retssikkerhed, der spiller ind her, sikring mod vilkårlighed og anden uretfærdighed, og den er da sympatisk nok, men den har det med at forhekse forstanden og blive et mål i stedet for et middel til et ordentligt samfund.

Altså: Alting kan måles. Det kræver bare en målestok. På nogle områder er det imidlertid svært at finde en målestok, og så kan man forfalde til at interessere sig for det letmålelige i stedet. Alle tvivlsspørgsmål kan afgøres. Det kræver bare nogle kriterier at afgøre dem efter. Men passede målestok og kriterier også til det, vi egentlig interesserede os for? Gav de vejledende regler en vejledning, vi kunne bruge - som førte os til en beslutning, der er bedre, end vi ellers kunne have nået? Når man står med en hammer, ligner alting som bekendt et søm, hvis man ikke lige får stoppet op og kigget ordentligt efter.

\section{Et liv uden etiske regler}

Man kan ikke rigtig beskylde Vejledende regler for god presseskik for at være for snærende. De er i det store og hele varm luft. Hovedparten af dem er formuleret helt vagt og abstrakt, præget af ord som 'bør' og 'så vidt muligt' og 'hvor det er rimeligt'.

Umiddelbart tror jeg ikke, de gør en forskel overhovedet.

Derfor kan der måske godt være gode grunde til at have dem. I det mindste det, man kalder eksterne grunde. Hvis reglerne forsvandt i morgen, ville nogen udefra måske påtvinge os et nyt regelsæt, som var alt for restriktivt. Desuden er det sikkert godt for 
branchens image, at vi har et regelsæt og noget selvjustits, plusminus. Ethics pays, som de siger i Amerika.

Men hvilke interne grunde kan der være til at have dem? Selv om det er min klare fornemmelse, at reglerne aldrig bliver trukket ind i, hvad der måtte være af diskussioner og overvejelser ude på redaktionerne, kan man godt forestille sig, at de ligger i baghovedet på journalister og chefer. De kender og accepterer dem, så de indgår som en del af den bagage, de hver dag går på arbejde med. På nøjagtig samme måde, som de fleste mennesker ikke behøver slå op på eller minde sig selv om reglen om, at man ikke må være to mod én. Men engang var det en ny og overraskende og måske svært forståelig regel for dem, det har de bare glemt i dag. Så for de nye generationers skyld skal reglerne stå et sted. Sådan gør man i en skriftkultur, kunne man argumentere.

Så skal de stå et andet sted, vil jeg hævde. Fordi konteksten, de står i, giver faget og branchen og samfundet en falsk fornemmelse af styr på sagerne.

Man kunne også begrunde regelsættet med, at truslerne om sanktioner kunne betyde noget. Der er næppe tvivl om, at der er prestigetab forbundet med at tabe en sag i Pressenævnet, spørgsmålet er bare, om det har en generalpræventiv effekt.

Jeg tror, at de fleste redaktioner i de fleste situationer oprigtigt mener, deres valg er sagligt og konkret begrundede (- når de ikke lige er udtryk for sjusk og fortravlethed), og står ved dem, også når de bliver underkendt. Og gør man det, sidder man vel ikke samtidig og fedter med at opveje risikoen for sanktion.

Tilbage er, om Pressenævnets udredninger i årsberetningen giver stof til overvejelser og diskussioner. Det er jeg ikke i tvivl om, at de gør. Spørgsmålet er, om den funktion kan klares uden regelsættet.

\section{De usynlige regler}

Men ét er, at man måske kan forestille sig, at der ikke findes den slags regler, der er formuleret af autoriteter og med vedhæftede sanktionsmuligheder. Noget andet er, at det er en rent sproglig sandhed, at vi følger regler - principper, om man vil - i alt, hvad vi gør. Standarder, procedurer, tankemønstre, kommunikation, 
alt. I langt de fleste tilfælde vælger vi ikke, om vi vil følge en regel. Vi følger den blindt, som Wittgenstein har formuleret det. Han påpeger også, at de færreste regler er formuleret og indlært os som regler. Vi har bare indoptaget dem ubevidst ved at deltage i aktiviteter sammen med andre (Wittgenstein, 1994).

Dewey er inde på noget af det samme i sin analyse af, hvordan vi løser problemer.

Der er grundlæggende tre metoder, hævder han. Der er for det første trial and error, som for ham betyder famlen sig frem på må og få eller fra en ende af, indtil man falder over det, der virker. Det kan tage tid, og somme tider kan man nå at gøre en del skade undervejs. For det andet er der rå fysisk vold på de ting eller mennesker, som opfattes som problematiske, men også den metode har en del mulige bivirkninger. Og endelig er der for det tredje, hvad man i første omgang bredt kunne kalde omtanken: At man prøver at analysere situationen og sammenholde den med noget kendt for at forestille sig, hvad der kunne ske, hvis man handlede sådan og sådan. Det kendte, man sammenholder med, er somme tider en tidligere, tilsvarende situation, somme tider et princip.

I en vis forstand er en tidligere situation og et princip to sider af samme sag, for det at uddrage erfaring af tidligere oplevelser er netop at udlede en regel eller et princip af det: 'Noget tyder på, at borgmestre, der har taget af kassen, reagerer sådan og sådan, når man spørger dem, så denne gang må jeg hellere..' Og når man så har fundet og testet den gode måde at tackle den slags situationer på, er det hip som hap, om man snakker om præcedens eller princip. Andre principper er alt for abstrakte til, at vi selv har kunnet erfare os til dem. Vi har arvet dem fra forgangne slægter, men overordnet gør det ingen forskel.

Et princip er i bund og grund en generalisering, siger Dewey, uanset om man selv har formuleret den eller har overtaget den fra andre.

En af Deweys pointer er, at vi kun undtagelsesvist i klassisk forstand vælger, hvilke principper vi vil bruge til at afgøre et tvivlsspørgsmål med. Tværtimod er det princippet, der kommer til os. Det byder sig til, spontant. Hvis vel at mærke det er et 'ægte' princip, og med det mener han et, der fører til skelnen (Dewey, 1991). Der skal være noget, der falder udenfor. Nogle får skal kunne 
skilles fra nogle bukke ved hjælp af princippet. Dewey kommer ikke med eksempler, men jeg tror, han ville kategorisere det her som et 'falsk' princip: 'Der bør vises særligt hensyn over for personer, som ikke kan ventes at være klar over virkningerne af deres udtalelser.' (Vejledende regler for god presseskik, B5). Der er ingen hjælp til at vide, hvad der tæller som et 'særligt hensyn', endsige hvem der på forhånd kan regnes som stærke nok til at kunne overskue virkningerne af det, de siger.

„Det generelles væsen er anvendelighed“, siger Dewey.

Det handler ikke om at kende principper nok, pointerer han. For ,viden er ikke visdom, information garanterer ikke god dømmekraft“ (Dewey, 1991: 107).

Så i følge Dewey består problemløsning først og fremmest i at få styr på situationen. Det vil sige få alle kendsgerninger frem og finde frem til, hvilke af dem, der er væsentlige, og hvilke der bare larmer og gør sig til, men ikke skal tælle. Efter denne analytiske fase (analyse er at skille ting ad og vurdere dem enkeltvis) følger en syntetisk fase, hvor man først sætter enkeltdelene ind på rette plads, med den vægt og betydning, det nærmere eftersyn har givet dem, og derefter sætter dem ind i en større sammenhæng, sammenligner med noget andet, tænker konsekvenser af forskellige handlemuligheder.

I det ligger en be-tydning og en be-dømmelse. Altså, at man tillægger enkeltdelene og sammenhængen en mening, man tyder dem, og derefter fælder man en dom. Når dommen falder, falder den som en beslutning - helt bogstaveligt, den slutter, altså lukker sagen. Men samtidig bliver den helt eller delvist til en regel, som kan hjælpe med at afgøre lignende sager i fremtiden. Måske bliver den endda en del af erfaringen, så den slags tilfælde for fremtiden slet ikke bliver opfattet som problematiske.

Det er her, værdien af diskussioner af tvivlssager har deres store pædagogiske berettigelse. Det er derfor, Pressenævnets afgørelser er eller kan være nyttige. Det er derfor, dilemmaspil af alle slags er så opbyggelige. 


\section{Dømmekraft}

Adskillige filosoffer har beskæftiget sig med begrebet dømmekraft. Allerede Kant skelnede mellem en bestemmende og en reflekterende dømmekraft, altså evnen til at bedømme en situation rigtigt og derefter finde ud af, hvad der skal gøres.

For de fleste filosoffer (men bestemt ikke for Kant) er der et vigtigt element af det, vi normalt på dansk kalder 'sund fornuft' i dømmekraften. Sund fornuft er en lidt underlig fordanskning af de gamle romeres begreb Sensus Communis, som på engelsk blev til common sense, som altså snarere er 'den fælles, almindelige opfattelse'. Men det danske udtryk har utvivlsomt fanget en vigtig bibetydning i det latinske forlæg: Det er noget befriende sundt over det, som forekommer umiddelbart indlysende for flertallet, sat op mod netop for stiv logik og for stive regelsæt. Romerne skelede formentlig til det aristoteliske begreb 'phronesis', som normalt oversættes til 'praktisk visdom' eller 'praktisk fornuft', og som betyder, at man ved, hvad der skal gøres i en bestemt situation. Fordi man er i stand til at bedømme situationen nuanceret og korrekt. Underforstået: Uden at forlade sig bevidstløst på teorier og præcedens.

Dømmekraft kommer med erfaring, betoner de fleste. Den kan ikke læres i et auditorium, men den kan indøves gennem praksis. Det betyder ikke, at erfaring altid medfører praktisk visdom. Somme tider er 20 års erfaring som bekendt bare ét års erfaring, reproduceret 19 gange. Det er den fornuftigt reflekterede praksis, der skærper dømmekraften.

Fornemmelsen for, hvilket princip den her sag falder ind under, er en del af dømmekraften, men Dewey betoner, at det ikke sker som en slags andet led i en beslutningsproces. Eller i al fald ikke i de fleste tilfælde. Men som nævnt snarere som en 'åbenbaring' - det er ikke Deweys udtryk, han kalder det intuition. Hovedpointen her er, at Dewey mener, at det afgørende i problemløsning ligger i analysen af de foreliggende kendsgerninger, ikke i valg af principper at bedømme situationen efter.

Ikke fordi der ikke er principper på spil, men fordi de primært spiller sig selv. 
Det er i al fald det, der sker, når vi ikke er i tvivl. I alle de mange tilfælde, både i journalistikken og i privatlivet, hvor vi bare handler uden at stoppe op og overveje, er det helt tydeligt, at principperne, vi handler efter, slet og ret viser sig. Eller, det er et upræcist udtryk, for vi ser dem netop ikke. De virker bare bag om ryggen på os.

Men de principper, der forventes at åbenbare sig, når man står og har brug for dem, hvordan kommer de ind i hovedet, så de er klar? På samme måde som al anden viden, vi trækker på. Noget har vi læst os til eller hørt om, noget har vi selv tænkt os frem til og noget har vi erhvervet som tavs viden gennem praksis.

Når vi lærer vore børn, hvordan man omgås andre, er der vist meget få, der snakker ytringsfrihed. Først og fremmest fordi vi bare ikke tænker i de baner, men hvis vi gjorde det, ville vi også hurtigt indse, at det forplumrer emnet. Det er en unødig omvej at gå at forklare sit barn, 'at ganske vist har du en grundlovssikret ytringsfrihed, men den er begrænset af en lang række andre hensyn. Den afvejning kan egentlig kun foretages af domstolene, men indtil de eventuelt har talt, vil jeg ikke høre dig vedvarende bruge ringeagtsytringer og ukvemsord over for dine kammerater'. Nej, vi går mindst ét skridt ned ad abstraktionsstigen og siger til barnet, at mobning er forkert. Måske går vi yderligere et par skridt ned og siger, at de og de ord vil vi under ingen omstændigheder høre igen. Eventuelt ledsaget af forklaringer, der skal opbygge en indlevelsesevne i barnet. Eller af trusler om sanktioner i gentagelsestilfælde.

Ytringsfrihed er et grundlæggende princip, som til daglig bare ligger som et usynligt fundament under vores samfund. Vi tænker (forhåbentlig) på indholdet af det, vi siger, og måske også på at finde en effektiv form at udtrykke det i. Men vi tænker ikke over, at vi er i færd med at udnytte vores ytringsfrihed, når vi bebrejder naboen eller statsministeren et eller andet, eller når vi foreslår chefen andre måder at lede på.

Når vi er hjælpsomme, tænker vi normalt heller ikke over, at vi efterlever et princip. Vi handler bare. Det er det normale: Vi scanner situationer, uden at pille dem fra hinanden, og så skrider vi til handling. Når vi kommer i tvivl, stopper vi op, analyserer situa- 
tionen, bedømmer den - og handler. Uden bevidst brug af et princip. Ville beslutningen blive bedre, hvis vi polerede et princip? Nej, det afgørende er, om vores analyse fik alle væsentlige aspekter med og bedømte dem rigtigt.

Selvfølgelig sker det, for eksempel for journalister, at vi sagligt set burde være i tvivl, men musikken spiller så højt og hurtigt og berusende, at vi glemmer det. Eller at princippet - eller modprincippet - slet ikke kan komme til at vise sig for al den adrenalin og begejstring. Så kan andre udfordre os på princippet eller principperne bag beslutningen, og somme tider er det vældig nyttigt at skulle eksplicitere det eller dem.

Jeg tror, man kan formulere det sådan her, næsten som en regel: Når nogen bliver endimensionelt principielle, er der brug for betoning af det specielle. Og når nogen bliver taktiske eller emotionelle i deres argumention, er der brug for at løfte fanen.

\section{Journalistikkens principper}

Lad os så vende os mod de principper, der er specielle for journalistikken.

Principper er udtryk for værdier, og en af de gængse definitioner på etik er væsentlige værdier i brug.

Så emnet kan formuleres som de grundlæggende værdier, der styrer, eller bør styre, journalistikken.

(Jeg taler udtrykkeligt om journalistikken, ikke om medierne eller pressen. Alt for mange er alt for tilbøjelige til at se bort fra det dialektiske forhold mellem journalistik og medier, de rører det sammen i én grød. Men det fører for vidt at komme mere ind på det her.)

Jeg har tidligere argumenteret fyldigt, for ikke at sige omstændeligt, for, at de grundlæggende journalistiske værdier ikke er nogle, man vælger. De udspringer af, hvad man kunne kalde journalistikkens natur. Altså af en forståelse af, hvad journalistik er (Bjerg, 2005). Her skal jeg gøre det kort: Journalistikkens opgave er at opdatere, justere og eventuelt finjustere borgernes verdensbillede, så det er mest muligt i overensstemmelse med virkeligheden på de områder, der er væsentlige for borgerne. Af dette 
grundlæggende princip, om man vil, kan man udlede flere ting. Først og fremmest, at det man fortæller, skal være sandt. Dernæst at det skal være væsentligt (det vil sige handle om noget, som er relevant for borgerens liv). At det skal leveres i en form, så modtageren vil tage imod det, tror på det og kan forstå det.

Så udspringer det også af en elementær forståelse af journalistikkens natur, at den udgør et voldsomt kraftfelt, som kan gøre både stor gavn og stor skade. Derfor skal den bruges med omtanke og ansvarlighed.

Der er en del andre værdier, men de udspringer allesammen af de her. De er så at sige udmøntninger, konkretiseringer af de fire store, så jeg vil for overskuelighedens skyld holde mig til dem.

\section{Søg sandheden.}

Hold dig til det, der er vigtigt.

Fortæl det spændende, troværdigt og forståeligt.

- Og skad mindst muligt.

Jeg kan ikke forestille mig, at nogen vil være uenig i det. Men jeg kan heller ikke forestille mig, at disse formuleringer gør en forskel for den praktiske journalist, som her møder dem for første gang. På samme måde som sætningerne 'Jorden er mere end 100 år gammel' og 'En elefant af almindelig elefantstørrelse kan ikke være i en tændstikæske' nok er helt nye sætninger for alle, der ser dem nu - og de vil ikke tvivle på, at de er sande - men sætningerne vil ikke give dem ny erkendelse.

For begynderen i faget kan det formentlig lette noget af indgangen. Blive en af nøglerne til at forstå de mange indforståetheder og indforståede selvforståelser, der er i ethvert fag.

Men ellers ville man under alle omstændigheder ret hurtigt blive præsenteret for de mange udmøntende regler: Hør altid modparten. Undgå så vidt muligt anonyme kilder. Tjek det én gang til. Forenkle uden at forsimple. Show it, don't tell it. Og så videre.

Og selv de mere konkrete regler bliver ret hurtigt noget, som får lov at blive liggende i baghovedet. Selvfølgeligheder, som man efterlever uden at skænke det en tanke. Præcist som vi følger reglen om højrekørsel i trafikken uden at tage stilling til den og uden 
at tænke på, at vi følger en regel. Selvfølgelig skal man tænke sig godt om, før man skriver grimt om andre. Selvfølgelig skal man holde sine aftaler med kilderne. Selvfølgelig skal man tjekke, om historien er sand. Selvfølgelig skal man så vidt muligt holde sine private sym- og antipatier ude af emnevalg og vinkelvalg og sprogbrug. Det behøver man ikke minde sig selv om hver morgen, før man går på arbejde. Princippet kommer til én, når man er på vej i uføre.

\section{Hvornår er det etik}

Her er det på sin plads at stoppe et øjeblik for at overveje, hvornår etikken så er i spil. På den ene side kan man argumentere for, at etikken er i det hele og hele tiden, for selv om vi ikke tænker over det, er alle vores handlinger, også som journalister, gennemsyret af værdier, og vi pådrager os hele tiden et ansvar for det, vi gør, og det, vi ikke gør. Hver gang vi møder til tiden, hver gang vi vælger at tage en bestemt historie op, vinkle den på en bestemt måde, opsøge nogle kilder og stille dem nogle spørgsmål og formidle det, vi finder ud af, efter en af de skabeloner, der plejer at virke - så kunne vi have pjækket, fundet en anden historie, vinklet den anderledes, fundet andre kilder, spurgt dem om noget andet og gengivet en anden del af det, de sagde, i en anden opbygning og et andet toneleje. Men intet af det, vi faktisk gjorde, behøver være udtryk for et bevidst valg. Og de færreste vil i den situation fornemme, at etikken har været med i deres arbejde.

Etik kommer først og fremmest op på dagsordenen, når man synes, at andre har gjort noget forkert. Dernæst, når man selv er i tvivl. Når man står over for et valg, som man opfatter som svært.

Det karakteristiske ved de situationer, hvor en journalist stopper op og måske oven i købet konsulterer en kollega eller sin chef, er ikke, at man mangler et princip. Det er, at to eller flere hver for sig gode principper kolliderer. Helt klassisk: Sand historie, væsentlig for borgerne, skader enkeltpersoner meget. Eller en anden udgave: Væsentlig historie, er ikke sikker på, at den er sand, vil skræmme borgerne. Eller en tredje: Sand og væsentlig historie, kan kun dokumenteres ved ufine metoder. 
Når etik er værdier i brug er det jo netop deres indbyrdes afvejning, det handler om. Hvad gør vi, når to hver for sig rigtige og fine principper tørner mod hinanden, og der ikke er plads til dem begge. Mange har forsøgt med forskellige modeller for 'etiske beslutninger', herunder at tildele de forskellige aspekter points, så man kan tælle sammen og se, hvilken beslutning, der er bedst. Det er igen princippet om at finde noget at måle, så man er fri for at være i tvivl og tage ansvar.

Men det står altså ikke indgraveret i noget princip, hvornår det overtrumfer et andet.

\section{Hold på principperne}

Her er det, Deweys tanker om problemløsning kommer ind. Som jeg forstår ham, vil han ikke mene, at vi bruger etiske regler eller noget, der ligner, når vi står i det, man normalt kalder et etisk valg. Vi analyserer situationen, tænker handlemuligheder og alternativer og konsekvenser. Derefter fælder vi en dom.

Hvis vi går tilbage til, hvordan vi formulerer principper for vore børn, vil det i de fleste tilfælde være fyldestgørende, hvis man fortæller dem, at man skal tale pænt til hinanden og ikke slå - navnlig hvis man i praksis selv viser, hvordan man gør det. Men de fleste forældre og lærere vil uden videre også acceptere, at barnet overtræder princippet i situationer, hvor det bliver kraftigt forulempet. Princippet om pænhed kolliderer mod princippet om ret til at slå fra sig, og det dilemma bedømmes ikke ud fra en regel. Der er ingen principper for, hvordan man vægter de to principper over for hinanden. Udover at der skal være en form for proportionalitet mellem krænkelse og respons. Men der er masser af praksis og diskussioner bagefter om grænsetilfælde. Mere eller mindre kvalificerede diskussioner, men de får ikke mere kvalitet af, at der er formuleret såkaldt etiske regler. Det rækker uden.

Det rækker endda bedre, for når de store principper bliver kørt i stilling, går der let religionskrig i uenigheden, og så bliver det som regel sværere at finde en løsning.

Vi er bedre tjent med at snakke kvalitet og snakke konkret end at snakke etik og principielt.

Sådan er det også med journalistikkens problemer. 
22 // JOURNALISTICA $\cdot 1 \cdot 2006$

\section{REFEREN CER}

Lars Bjerg (2005), Voer god-om etik, vaerdier og kvalitet i journalistik, Århus: Ajour.

John Dewey (1991, opr. 1910), How we think, New York: Prometheus Books.

Karl Popper: (1934), The Logic of Scientific Discovery, Routledge.

Ludwig Wittgenstein (1994, opr. 1958), Filosofiske undersøgelser, København: Munksgaard. 